\title{
Dietary compounds as potent inhibitors of the signal transducers and activators of transcription (STAT) 3 regulatory network
}

\author{
Anne Trécul • Franck Morceau • Mario Dicato • \\ Marc Diederich
}

Received: 12 October 2011/Accepted: 10 January 2012/Published online: 25 January 2012

(C) Springer-Verlag 2012

\begin{abstract}
Signal transducers and activators of transcription (STAT) proteins were described as a family of latent cytosolic transcription factors whose activation is dependent on phosphorylation via growth factor- and cytokine-membrane receptors including interferon and interleukin, or by nonreceptor intracellular tyrosine kinases, including Src. A vast majority of natural substances are capable of modulating mitogenic signals, cell survival, apoptosis, cell cycle regulation, angiogenesis as well as processes involved in metastasis development. The inhibition of STAT3 phosphorylation by natural and dietary compounds leads to decreased protein expression of STAT3 targets essentially involved in regulation of the cell cycle and apoptotic cell death. This review details the cell signaling pathways involving STAT transcription factors as well as the corresponding compounds from nature able to interfere with this regulatory system in human cancer.
\end{abstract}

Keywords Cancer · Inhibitors · STAT3

\section{The family of STAT transcription factors}

Structure and function

STAT (signal transducers and activators of transcription) proteins were originally described as a family of cytoplasmic transcription factors. In mammals, seven members of this family, each consisting of 750-900 amino acids,

A. Trécul · F. Morceau · M. Dicato · M. Diederich $(\bowtie)$ Laboratoire de Biologie Moléculaire et Cellulaire du Cancer, Fondation de Recherche Cancer et Sang, Hôpital Kirchberg, 9 Rue Edward Steichen, 2540 Luxembourg, Luxembourg e-mail: marc.diederich@lbmcc.lu have been identified: STAT1, STAT2, STAT3, STAT4, STAT5a, STAT5b and STAT6. These transcription factors act as dimers (homo- or hetero-dimers), and their activation is dependent on their phosphorylation or via membrane receptors stimulated by either extracellular factors, including interferon (IFN) and interleukin (IL-6), or by intracellular kinases independent of receptors, including Src. Activation of STATs is usually transient and highly regulated. STAT proteins contain seven conserved structural and functional domains (Fig. 1a) (Schindler and Plumlee 2008).

First, the amino terminal $\mathrm{NH}_{2}$ domain is involved in the dimerization of STAT proteins and in the stabilization of the interaction established between these dimers and DNA response elements (Braunstein et al. 2003; Mertens et al. 2006). The coiled-coil domain is responsible for controlling the process of import and export of proteins into and from the nucleus (Schindler et al. 2007). The domain that binds DNA, or the DBD (DNA binding domain), is involved in the physical interaction with STAT3-response elements in the promoters of target genes. With the exception of STAT2, all activated STAT homodimers bind directly to a palindromic sequence, the GAS (IFN-gammaactivated site), TTTCCNGGAAA (Becker et al. 1998). The "linker" domain localizes the active dimer to the DNA binding site. The transcriptional activation domain (TAD) contains sites of phosphorylation of serine residues that allow the recruitment of coactivators such as RNA polymerase II, histone acetyltransferase (HAT) (Paulson et al. 2002), histone deacetylase (HDAC) (Rascle et al. 2003) and chromatin modification complexes.

Finally, two sites are particularly critical for the activity of STAT. These are the SH2 domain (Src homology 2, amino acids 575-680), which is linked to the DBD by the linker domain, and a conserved tyrosine close to residue 
A

\begin{tabular}{|l|l|l|l|l|l|l|l|}
\hline NH2- ND & CCD & DBD & Linker & SH2 & Y & TAD & COOH \\
\hline
\end{tabular}

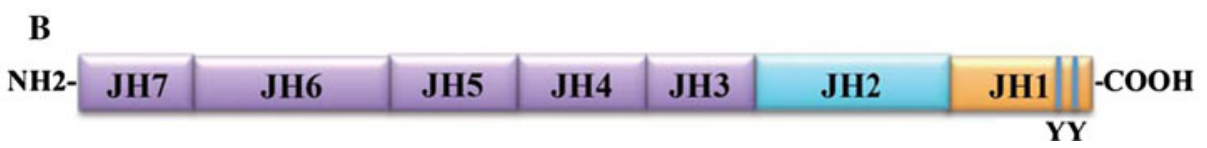

Fig. 1 a Schematic representation of the structural domains of STAT proteins, adapted from (Liu et al. 2002). The STAT protein contains an N-terminal domain $(N D)$ responsible for stabilizing the binding of STAT dimers to DNA. The "coiled-coil" domain $(C C D)$ is involved in interactions with other proteins. The DNA binding domain $(D B D)$ allows physical contact with the STAT response elements in the promoter of target genes. The linker domain connects the DBD to the "Src homology 2" domain (SH2) and is important in the dimerization of STAT proteins. A tyrosine residue $(Y)$ in the TAD domain is phosphorylated and interacts with the $\mathrm{SH} 2$ domain of another monomer. The C-terminal TAD area is responsible for the

700. The SH2 domain is highly conserved and allows for the recruitment of specific STAT proteins to the intracellular chains of membrane receptors and participates in the formation of active dimers from STAT monomers. The tyrosine residue close to position 700 in the inactive STAT monomer is phosphorylated by protein kinases of the Janus family kinases (JAK) associated with specific membrane receptors that promote the recruitment of this monomer. Interaction with STAT results from the stimulation of membrane receptors following an extracellular signal that is transduced by cytokines, growth factors and other polypeptide ligands.

\section{The JAK/STAT signaling pathway}

The interaction between ligands and specific receptors, which are associated with JAK proteins, triggers receptor dimerization. This dimerization is followed by transphosphorylation, which is required for the activation of JAK proteins. Receptors associated with the JAK/STAT signaling pathway are class I (hematopoietin) and class II (interferon) cytokine receptors. These receptors have a transmembrane domain, and their extracellular region binds the ligand (cytokine), whereas their intracellular domain is used for the interaction with JAK and STAT. The JAK/STAT signaling pathway is highly conserved during evolution. It was first identified in vertebrates, where this signal transduction pathway was found to be activated by cytokines.

JAK proteins belong to a family of intracellular tyrosine kinases with a molecular weight of 120-140 kDa. In mammals, this family of proteins is composed of four members: JAK1, JAK2 and Tyk2, which are widely expressed in a variety of different cell types, and JAK3, transcriptional activation of target genes. Areas in purple represent the different sites of action of specific inhibitors of STAT3 that have been recently identified. b Schematic representation of the structural domains of JAK proteins, adapted from Braunstein et al. (2003). The $\mathrm{N}$-terminal region of the JAK protein contains the JH3-JH7 domains (shown in purple) that are involved in protein binding with the receptor. Next, the $\mathrm{JH} 2$ domain (shown in blue) corresponds to the domain pseudokinase necessary to regulate the catalytic activity of JH1. The JH1 domain is found in the C-terminal and contains the kinase activity. This domain contains two tyrosines that play an important role in protein kinase activity

which is mainly found in hematopoietic cells. JAK was first identified in 1989 and was termed Just Another Kinase. Later, this protein was renamed Janus Kinase (JAK), after the Roman god, because it has a kinase domain and a "kinase-like" domain that regulates the kinase domain (Pellegrini and Dusanter-Fourt 1997).

These proteins possess various domains, as shown in Fig. 1b. The C-terminus of the protein, JAK homology domain $\mathrm{JH} 1$ for domain 1, carries the kinase activity. This domain is structured as a loop involving two tyrosines that play a very important role in regulating kinase activity. For example, for JAK2, tyrosine residues 1007 and 1008 are phosphorylated. A single mutation of tyrosine 1007 suppresses the tyrosine kinase activity of JAK2 (Heinrich et al. 1998). The JH2 kinase-like domain precedes the JH1 domain. This domain may affect kinase activity, but there is no clear explanation found in the literature. Within the $\mathrm{N}$-terminus of the protein, the 5 domains ranging from JH3 to $\mathrm{JH} 7$ are involved in the interaction with the receptor. These domains contain conserved sequences found in various JAK proteins (Pellegrini and Dusanter-Fourt 1997).

JAK proteins phosphorylate the cytoplasmic domain of the receptor at tyrosine residues (Fig. 2). These phosphorylated residues are important in recognizing the monomeric and cytoplasmic STATs. STAT proteins are recruited to the phosphorylated tyrosine receptor via their $\mathrm{SH} 2$ domain and are then phosphorylated by JAK at tyrosine 705 ; then, the phosphorylated STAT monomers dimerize. The interaction between the two monomers is established by an interaction between the $\mathrm{SH} 2$ domains and phosphorylated tyrosines. The dimer is then imported into the nucleus by importins (Benekli et al. 2009). In the nucleus, active STAT will bind to specific regulatory elements (GAS) within regulatory promoter sequences of target genes. JAK proteins can then 


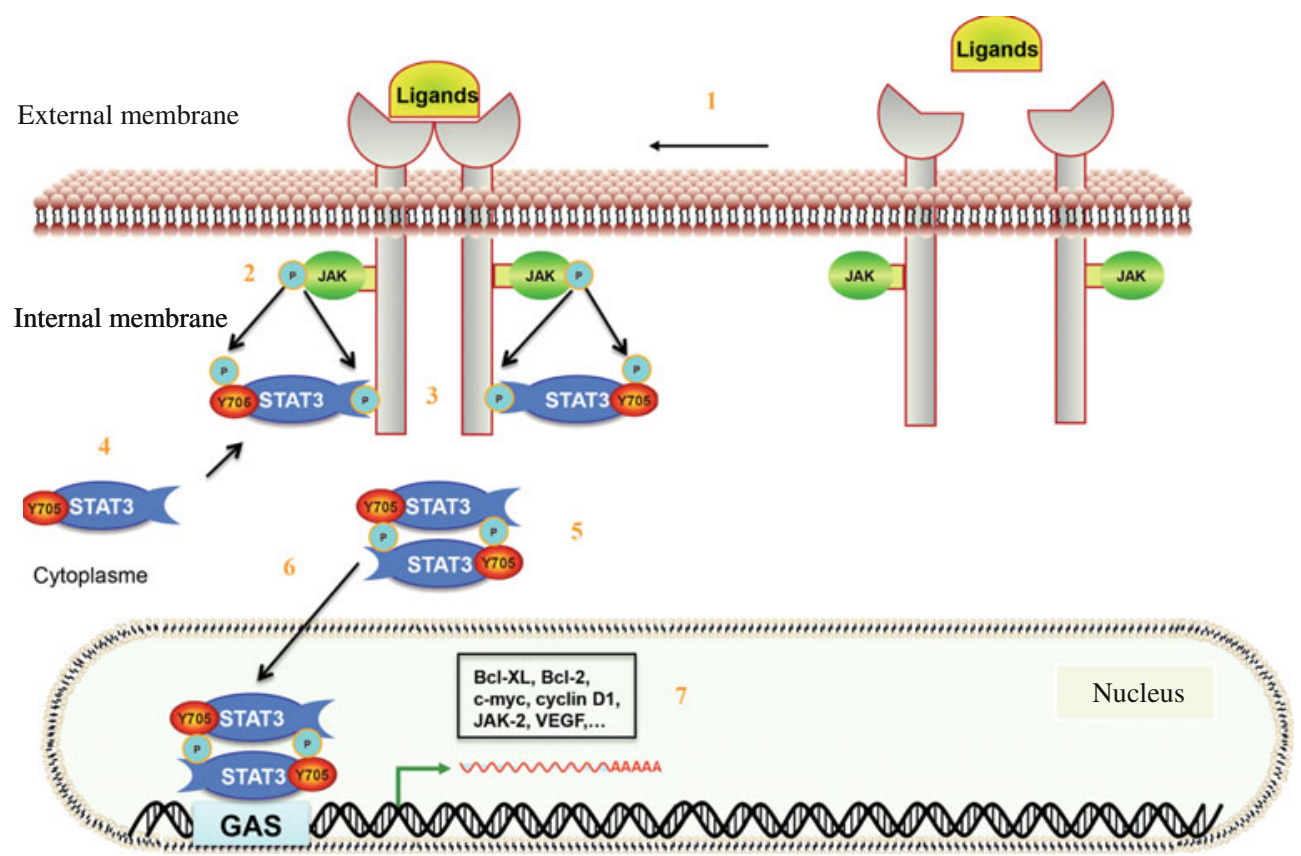

Fig. 2 The JAK/STAT signaling pathway. Ligand binding to the membrane receptor leads to receptor dimerization (1) and activation of associated JAK proteins (2). JAK phosphorylates the receptor (3) to recruit and phosphorylate cytoplasmic STAT factors (4). Phosphorylation of STAT factors leading to their dimerization (5). As a

activate the transcription factor STAT, but it is possible that other proteins may also activate this factor. For example, the protein tyrosine kinase Src may cause dimerization of the transcription factor STAT also resulting in the activation of selected target genes (Darnell 1997).

\section{Involvement of STAT3 in cancer}

The STAT family of transcription factors plays an important role in many cellular events, including differentiation, proliferation, inflammation and the immune response. In fact, disruption of the mechanism leading to constitutive activation of STAT is considered to be a cancer-promoting factor (Benekli et al. 2003).

Constitutive activation of STAT is associated with malignant transformation induced by various oncoproteins that are tyrosine kinases, such as Src (sarcoma viral oncogene homolog), Bcr-Abl (breakpoint cluster regionAbelson) or EGFR (epidermal growth factor receptor) (Ilaria and Van Etten 1996; Ozawa et al. 2008). The target genes of STATs, such as cyclins D1/D2, Myc, Bcl-xL and Mcl-1 among others, appear to contribute to oncogenesis by activating cell cycle and inhibiting apoptosis (EplingBurnette et al. 2001; Ozawa et al. 2008). The constitutive activation of these transcription factors indeed generates a deregulation of growth and cell survival, invasion of tumor dimer, STAT will be translocated into the nucleus (6) to specifically bind to DNA at the GAS (IFN-gamma-activated site). The STATE dimer activates the transcription of its target genes (7). This figure presents STAT3 and its target genes in the nucleus as an example

cells and thus the formation of metastasis, an increase in angiogenesis and suppression of immune surveillance of the tumor. STAT3 transcription factor is frequently activated in cell lines and leukemic blasts of patients with acute lymphoblastic leukemia (ALL) or acute myeloid leukemia (AML) (Spiekermann et al. 2001). Moreover, STAT3 has also been involved in a wide range of cancer types including multiple myelomas (MM), cutaneous T-cell lymphomas (CTCL), hepatocellular carcinomas (HCC), cholangiocarcinomas (CCA), as well as prostate and pancreatic cancers.

Genetic and biochemical studies have highlighted the key role of STAT3 in signal transduction induced by cytokines, including IL-6, IL-10 and IFN. Knockout mice for STAT3 exhibit early embryonic mortality consistent with its multiple activities, and STAT3 gene extinction in specific tissues has been associated with an inflammatory response, developmental abnormalities and decreased oncogenic potential. Instead, hyperactivation of STAT3 has been associated with immunosuppression and cellular transformation. Compared to healthy cells, where STAT activation is highly regulated, some solid tumor and hematological cancers maintain constitutive activity of STAT3 protein phosphorylation. Accordingly, a clear link between the aberrant activation of STAT3 and tumor formation has been depicted in the literature. Indeed, it was shown that constitutively active STAT3 could cause the inhibition of tumor suppressive activity of p53 by binding 
to the p53 promoter (Niu et al. 2005). In addition, recent studies have shown that activation of the STAT3 gene leads to the overexpression of AKT, a key target of phosphatidylinositol 3-kinase (PI3K) that is constitutively activated in acute myeloid leukemia (AML). PI3K regulates cell survival and resistance to chemotherapy via pathways that involve mitogen-activated protein kinase (MAPK) as well as transcription factors NF-kB and p53 (Grandage et al. 2005). STAT3 is mainly phosphorylated by JAK 2 in combination with a membrane receptor stimulated by a cytokine.

In leukemia, the JAK2 kinase presents a Valine $617 \rightarrow$ phenylalanine (V617F) mutation in the JH2 kinaselike domain. This mutation confers either hypersensitivity or independence to hematopoietic cytokines. Moreover, abnormal proliferation and survival of stem cells is affected by this mutation. In $50 \%$ of cases of acute myeloid leukemia (AML), STAT3 is constitutively active and this activation leads to many cellular processes, such as cell resistance to apoptosis (Zhao et al. 2011). Moreover, the survival of patients without constitutive phosphorylation of STAT3 has significantly increased. According to Staerk et al. (2007), the V617F mutation suppresses the inhibitory function of the JH2 pseudokinase domain over the kinase domain (JH1). Concerning this mutation, two assumptions were made. The first assumption was that mutant JAK2 could interact normally with the receptor and the complex formed between the receptor and JAK2 V617F entity would be considered to be constitutively active. The second was that the V617F mutation could trigger pathological activation, thereby causing persistent phosphorylation of JAK2 V617F tyrosine at 1007 , or at one or more of the 49 known tyrosines within the primary sequence of JAK2. The human erythroleukemia cell line HEL presents the V617F mutation within the JAK2 gene and represents an interesting model to study this mutation and the cellular dysfunctions that it generates. This cell line was established from cells collected in the pleural fluid of a 30-year-old patient suffering from acute myeloid leukemia (AML) (Martin and Papayannopoulou 1982).

Multiple myeloma (MM) is a clonal B-cell neoplasm characterized by an accumulation of neoplastic plasma cells that leads to reduced patient survival (Damber and Aus 2008). As for many types of leukemia, STAT3 is considered to be one of the main factors involved in the pathogenesis and chemoresistance of MM, therefore resulting in a high mortality rate. Indeed, MM cells have been shown to express constitutive activated STAT3 in correlation with the overexpression of the anti-apoptotic proteins Bcl- $\mathrm{x}_{\mathrm{L}}$ (Catlett-Falcone et al. 1999; Grad et al. 2000; Tu et al. 1998) and Bcl-2 (Pettersson et al. 1992). On the other hand, recent studies have revealed a key role for chronic inflammation in the different stages of prostate cancer progression (Bhutani et al. 2007). Indeed, prostate cancer proliferation, survival, invasion, metastasis and angiogenesis are linked to the NF- $\kappa \mathrm{B}, \mathrm{STAT} 3, \mathrm{AKT}$ and COX-2 signaling pathways (Chan et al. 2010; Shanmugam et al. 2011b). However, NF- $\kappa$ B and STAT3 have been particularly implicated in cell survival, metastasis and angiogenesis of prostate tumors (Gojo et al. 2002). Moreover, STAT3 is often constitutively activated in hepatocellular carcinoma (HCC) (Liu et al. 2002; Niwa et al. 2005) where it induces cell growth and inhibits apoptosis. Interestingly, a clear link between hepatitis $\mathrm{C}$ virus (HCV), STAT3 activation and HCC development has been reported (Waris and Siddiqui 2005; Yoshida et al. 2002). As described by many studies, STAT3 represents a good candidate as a target in HCC patients for therapeutic agents including natural compounds ( $\mathrm{Li}$ et al. 2010; Rajendran et al. 2011a, b; Tan et al. 2010).

\section{Inhibition of STAT}

Introduction

To reduce the aberrant activation of STAT proteins, there are several treatment strategies that target these proteins. In particular, it is possible to inhibit specific membrane receptors, tyrosine kinases, mRNAs and proteins that activate STAT. For several years, synthetic compounds inhibited STAT factors by various molecular mechanisms. These inhibitors block the translocation step of the active dimer from the cytoplasm to the nucleus and act at the point where the dimer binds to DNA. Many naturally occurring substances have also appeared in the list of molecules that are potentially active antitumor agents through specific inhibition of STAT.

Constitutive expression of activated STAT factors leads to tumor promotion; therefore, specific inhibition of these mechanisms should preferentially target cancer cells without affecting other cells. Therapeutic strategies considered for the treatment of leukemia and non-hematological cancers (Jing and Tweardy 2005) would specifically target activation of STAT factors, such as the inhibition of transmembrane receptors and associated downstream signaling, or more directly STAT activity. A specific antibody, rituximab, could inhibit the CD20 transmembrane antigen expressed by B cells in non-Hodgkin lymphoma cells, leading to the inhibition of constitutive STAT3 phosphorylation (Alas and Bonavida 2001). These results demonstrate the relevance of a strategy to inhibit STATs via membrane receptors.

The inhibition of tyrosine kinases that are associated with receptors by specific inhibitors has been particularly studied in recent years. The inactivation of JAK2 by the tyrphostin AG490 is an example of the potential 
effectiveness of such a treatment to suppress constitutive STAT3 phosphorylation. Indeed, this molecule leads to the arrest of leukemic cell proliferation in vitro and in vivo (Meydan et al. 1996), and apoptosis of U266 myeloma cells (Jing and Tweardy 2005). Another tyrosine kinase inhibitor already in clinical use in the treatment of Bcr-Abl positive leukemia, imatinib, has been shown to have an inhibitory effect on the expression of the anti-apoptotic gene, Bcl-xL, which is a target gene of STAT5 (Horita et al. 2000). In addition, targeting very specific STAT factors can be achieved through the use of competitor peptides to prevent formation of STAT dimers (Turkson et al. 2001). Other strategies that use highly selective inhibitors of STAT mRNA include single-strand oligonucleotides or siRNA (small interfering RNA) (Lee et al. 2004).

Inducing in vitro growth arrest of tumor cells and apoptosis as well as tumor regression in vivo by inhibition of the constitutive activity of STAT3 is then conceivable by pharmacological or genetic approaches. Selected examples of STAT3 inhibitors are listed in Table 1 (Yue and Turkson 2009). Some molecules will directly target the SH2 domain of the protein to prevent dimer formation and thus the formation of active STAT3. For example, a non-peptide small molecule called Stattic selectively inhibits STAT3 by directly binding to the SH2 domain (Schust et al. 2006). The SH2 domain of STAT3 is indeed critical for the activation of STAT3 and its translocation to the nucleus. Therefore, Stattic has a selective inhibitory effect on activation, dimerization and translocation to the nucleus, while also increasing induction of apoptosis.

Other inhibitors, including CPA-1, CPA-7 (Turkson et al. 2004) or IS3 295 (Turkson et al. 2005), act at the level of the DBD domain responsible for binding of STAT3 to DNA. They block the transcriptional activation of STAT3 target genes. Inhibitors that inhibit the transcriptional activity of STAT3 without affecting phosphorylation may also target the N-terminus. In addition, the use of siRNA and antisense RNA induced apoptosis of tumor cells and tumor regression (Lee et al. 2004). Other strategies inhibit steps upstream of the activation of STAT3. For example, it is possible to use inhibitors of tyrosine kinase to prevent phosphorylation of STAT3.

\section{Natural STAT3 inhibitors and cancer}

A vast majority of natural substances are capable of modulating mitogenic signals, cell survival, apoptosis, cell cycle regulation, angiogenesis as well as processes involved in metastasis development. In addition, many natural compounds have been studied in order to elucidate their roles in the signaling pathways implicated in cancer. The chemical structures of the natural compounds with inhibitory activity on STAT3 cited in this review (in italics) are presented in the Fig. 3. Studies have shown that the natural compound, cryptotanshinone (Shin et al. 2009), is able to inhibit the rapid phosphorylation of tyrosine 705 in STAT3 and thereby blocks the growth of prostate cancerderived cells. The inhibition of STAT3 phosphorylation leads to decreased protein expression of STAT3 targets, including cyclin D1, which regulates the cell cycle, survivin, which is responsible for the inhibition of caspase activation, or the anti-apoptotic protein Bcl-xL, which belongs to the $\mathrm{Bcl} 2$ protein family and is involved in the survival of cancer cells. This natural compound may also bind directly to STAT3 molecules at the SH2 domain-level to block the formation of STAT dimers. Likewise, capsaicin (trans-8-methyl- $N$-vanillyl-6-nonenamide), one of principal ingredients of chili from the plant Capsicum (Solanaceae), can suppress carcinogenesis of the skin, colon, lung, tongue and prostate. Bhutani et al. demonstrated the mechanisms of inhibition of STAT3 in multiple myeloma cells. According to these studies, capsaicin is able to block both the inducible and the constitutive activation of STAT3; this effect is correlated with downregulation of the expression of the genes involved in cell survival, proliferation and angiogenesis (Bhutani et al. 2007). Furthermore, the inhibition of STAT3 activation can significantly reduce the pool of nuclear STAT3. This work also showed that capsaicin is able to suppress the dosedependent binding activity of STAT3 to DNA and that this compound may also inhibit the constitutive activation of several kinases, such as JAK1, c-Src and ERK.

\section{Multiple myeloma}

Many chemotherapeutic drugs have been used for many years to treat MM patients with variable efficiencies; these drugs include melphalan, prednisone, alkylating agents, Vinca alkaloids and more recently, thalidomide and its derivatives as well as the proteasome inhibitor bortezomib. Moreover, patients frequently develop resistance to these treatments (Dimopoulos et al. 2003).

STAT3 is considered to be one of the main factors involved in the pathogenesis and chemoresistance of MM, therefore resulting in a high mortality rate. Besides its effect on STAT proteins in leukemia cells, curcumin was also reported to be a reversible inhibitor of constitutive STAT3, but not STAT5 phosphorylation, in human MM cells (Bharti et al. 2003). This was correlated with the inhibition of STAT3 nuclear translocation in MM cells. Despite its structural similarities with the STAT3 inhibitor AG490, curcumin was shown to be more efficient as a STAT3 inhibitor in the U266 cell line (Meydan et al. 1996). On the other hand, the triterpene celastrol, a natural compound from a Chinese herbal product, has been studied 
Table 1 Inhibitors of STAT3 synthesis, their targets, mode of inhibition and cellular effects, adapted from Yue and Turkson 2009)

\begin{tabular}{|c|c|c|c|c|}
\hline Inhibitor & Target site & $\begin{array}{l}\text { Mode of inhibition } \\
\text { of STAT3 function }\end{array}$ & Cellular effects & References \\
\hline PY*LKTK & domain $\mathrm{SH} 2$ & Dimerization & $\begin{array}{l}\downarrow \text { Malignant cell growth } \\
\text { and transformation }\end{array}$ & Turkson et al. (2001) \\
\hline Y*LPQTV & domain $\mathrm{SH} 2$ & Dimerization & ND & Ren et al. (2003) \\
\hline SS610 & domain $\mathrm{SH} 2$ & Dimerization & $\begin{array}{l}\downarrow \text { Malignant cell growth } \\
\text { and transformation } \\
\uparrow \text { Apoptosis }\end{array}$ & Turkson et al. (2004) \\
\hline S3I-M2001 & domain $\mathrm{SH} 2$ & Dimerization & $\begin{array}{l}\downarrow \text { Malignant cell growth } \\
\uparrow \text { Apoptosis, } \downarrow \text { Migration }\end{array}$ & Siddiquee et al. (2007) \\
\hline STA-21 & domain $\mathrm{SH} 2$ & Dimerization & $\uparrow$ Apoptosis & Song et al. (2005) \\
\hline S3I-201 & domain $\mathrm{SH} 2$ & Dimerization & $\begin{array}{l}\downarrow \text { Cell growth } \\
\uparrow \text { Apoptosis }\end{array}$ & Siddiquee et al. (2007) \\
\hline Stattic & domain $\mathrm{SH} 2$ & Phosphorylation & $\uparrow$ Apoptosis & Schust et al. (2006) \\
\hline $\begin{array}{l}\text { Catechol-containing } \\
\text { compounds }\end{array}$ & domain DBD & DNA-binding & ND & Hao et al. (2008) \\
\hline IS3 295 & domain DBD & DNA-binding & $\begin{array}{l}\downarrow \text { Cell growth } \\
\uparrow \text { Apoptosis }\end{array}$ & Turkson et al. (2005) \\
\hline CPA-1, CPA-7 & domain DBD & DNA-binding & $\begin{array}{l}\downarrow \text { Cell growth } \\
\uparrow \text { Apoptosis }\end{array}$ & Turkson et al. (2004) \\
\hline Galiellalactone & domain DBD & DNA-binding & $\begin{array}{l}\downarrow \text { Cell growth } \\
\uparrow \text { Apoptosis }\end{array}$ & Weidler et al. (2000) \\
\hline Peptide aptamers & domain DBD & DNA-binding & $\begin{array}{l}\downarrow \text { Cell growth } \\
\uparrow \text { Apoptosis }\end{array}$ & Nagel-Wolfrum et al. (2004) \\
\hline Decoy ODN & domain DBD & $\begin{array}{l}\text { Compete against endogenous } \\
\text { DNA cis element }\end{array}$ & $\begin{array}{l}\downarrow \text { Cell growth } \\
\uparrow \text { Apoptosis }\end{array}$ & Leong et al. (2003) \\
\hline G-quartet ODN & domain $\mathrm{SH} 2$ & Phosphorylation & $\begin{array}{l}\downarrow \text { Cell growth } \\
\uparrow \text { Apoptosis }\end{array}$ & Jing et al. (2006) \\
\hline Peptides & ND & Transcriptional activity & $\begin{array}{l}\downarrow \text { Cell growth } \\
\uparrow \text { Apoptosis }\end{array}$ & Timofeeva et al. (2007) \\
\hline JSI-124 \& derivatives & JAK? & Phosphorylation & $\begin{array}{l}\downarrow \text { Cell growth } \\
\uparrow \text { Apoptosis, } \downarrow \text { invasiveness }\end{array}$ & Blaskovich et al. (2003) \\
\hline Withacnistin & JAK? & Phosphorylation & $\downarrow$ Proliferation, $\uparrow$ apoptosis & Sun et al. (2005) \\
\hline
\end{tabular}

$\uparrow$ increase, $\downarrow$ decrease

as an antiproliferative molecule of MM cells. Celastrol has various molecular targets, and its ability to modulate the expression of numerous proteins related to a wide range of cellular activities including pro-inflammatory cytokines, adhesion molecules, proteasome activity, topoisomerase II, potassium channels and heat shock response has been reported (Kannaiyan et al. 2011a). Kannaiyan et al. (2011b) reported that proliferation of MM cell lines was inhibited by celastrol in correlation with the inhibition of constitutive and induced activation of STAT3. The effect of $\mathrm{cel}$ astrol occurred in cells both sensitive and resistant to bortezomib. Furthermore, it enhanced bortezomib- and thalidomide-mediated apoptosis in MM cells, concomitantly in order to downregulate STAT3 target genes, including cyclin D1, Bcl-2, Bcl-xL, survivin, XIAP and Mcl-1. According to these results, the authors suggested that celastrol could potentially be used in the treatment of MM and other hematological malignancies (Fig. 4).

Acetyl-11-ketoh-boswellic acid (AKBA), another natural triterpenoid, is isolated from the Indian frankincense Boswellia serrata and exhibits anti-inflammatory and anticancer activities. $A K B A$ was reported to be an inhibitor of both constitutive and inducible STAT3 activation through the induction of the Src homology region 2 domain-containing phosphatase 1 (SHP-1). This effect correlated with an inhibitory activity on JAK and c-Src. Regarding the effect of this molecule, a downregulation of STAT3 target genes was expected, resulting in the 
<smiles>O=[N+]([O-])c1ccc2c(c1)S(=O)(=O)C=C2</smiles>

1 Stattic<smiles>COc1cc(CNC(=O)CCCC/C=C/C(C)C)ccc1O</smiles>

3 Capsaicin<smiles>CC1=C(O)C(=O)C=C2C1=CCC1[C@]2(C)CC[C@]2(C)C3CC(C)(C)CC[C@@]3(C)CC[C@]12C</smiles>

5 Celastrol<smiles>O=C(/C=C/c1ccc(O)c(O)c1)c1ccccc1O</smiles>

7 Butein

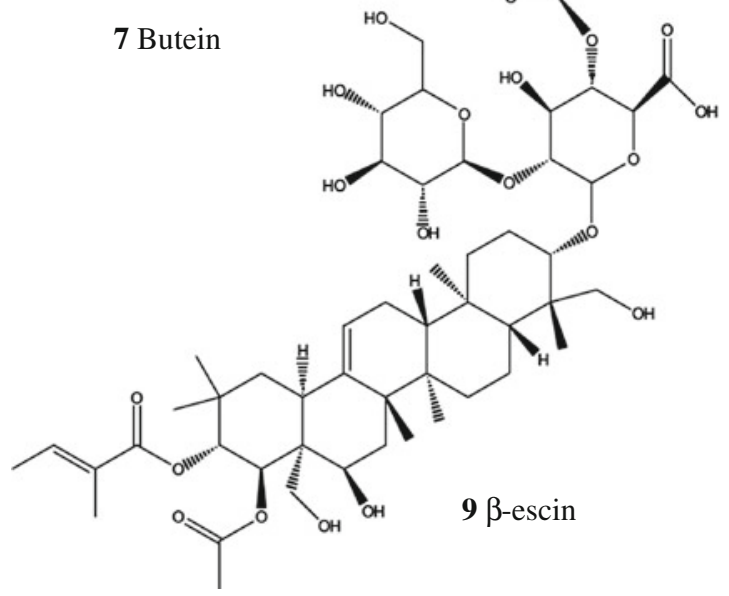<smiles>CC1COc2c1ccc1c2C(=O)C(=O)c2c-1ccc1c2CCCC1(C)C</smiles>

2 Cryptotanshinone<smiles>COc1cc(/C=C/C(=O)CC(=O)/C=C/c2ccc(O)c(OC)c2)ccc1O</smiles>

4 Curcumin<smiles>C[C@H]1CC[C@]2(C)CC[C@]3(C)C(=CC(=O)C4[C@@]5(C)CC[C@@H](O)[C@@](C)(O)C5CC[C@]43C)C2[C@@H]1C</smiles>

6 AKBA (Acetyl-11-Keto- $\beta$-Boswellic Acid<smiles>C[C@H]1CC[C@]2(O)CC[C@]3(C)C(=CCC4[C@@]5(C)CC[C@@H](O)C(C)(C)C5CC[C@]43C)C2[C@@H]1C</smiles>

8 Diosgenin<smiles>C[C@H]1CC[C@]2(O)CC[C@]3(C)C(=CCC4[C@@]5(C)CC[C@@H](O)C(C)(C)C5CC[C@]43C)C2[C@@H]1C</smiles>

10 Ursolic acid

Fig. 3 Chemical structures of different dietary STAT3 inhibitors

suppression of proliferation and induction of apoptosis in MM cells. However, besides its effect on MM cells, $A K B A$ was also shown to suppress the growth of glioma, colon cancer, prostate and leukemic cells. These effects on multiple cancer targets can occur through the inhibition of the extracellular signal regulated kinase 1 and 2 (ERK1/2) phosphorylation, NF- $\kappa \mathrm{B}$ pathway inhibition via $\mathrm{I} \kappa \mathrm{B}$ kinase (IKK) as well as topoisomerase I inhibition (Glaser et al. 1999; Hoernlein et al. 1999; Liu et al. 2002; Park et al. 2002; Shao et al. 1998; Syrovets et al. 2005). These 


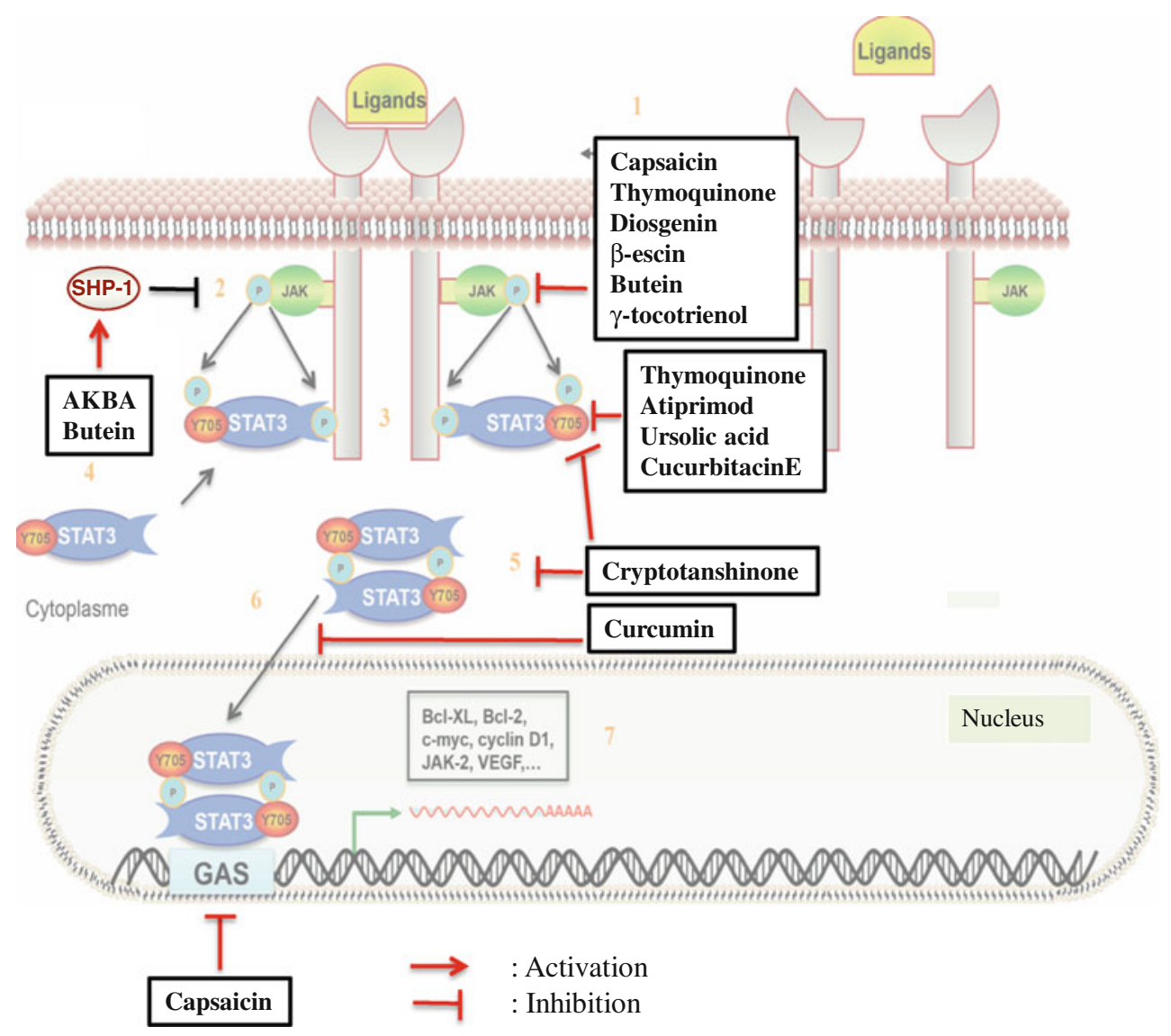

Fig. 4 JAK/STAT signaling pathway targeted by different inhibitors. These inhibitors target the following points in the JAK/STAT signaling pathway: constitutive activation of JAK2, STAT3 phosphorylation,

observations suggest that $A K B A$ does not specifically affect STAT3 activity but has a wide field of action.

Similarly, the main component isolated from the medicinal plant Nigella sativa, thymoquinone (TQ), was shown to inhibit both constitutive and IL-6-induced STAT3 phosphorylation. Moreover, $T Q$ potentiated the apoptotic effects of thalidomide and bortezomib in MM cells. Besides its inhibitory effect on STAT3-target genes, including proapoptotic ones, the mechanism of action of this natural compound has been proposed to involve the inhibition of c-Src and JAK2 activation as well as a protein tyrosine phosphatase. Indeed, while $T Q$ induced the expression of Src homology-2 phosphatase 2 in correlation with the inhibition of STAT3 phosphorylation, the phosphatase inhibitor vanadate reversed the $T Q$-induced downregulation of STAT3 activation (Li et al. 2010). Similar mechanisms were observed in MM cells with the natural chalcone $b u$ tein, which inhibited STAT3 activation by inducing expression of the tyrosine phosphatase SHP-1. Indeed, the deletion of the SHP-1 gene by small interfering RNA abolished the ability of butein to inhibit STAT3 activation (Pandey et al. 2009). formation of the STAT dimer and binding activity of STAT3 to DNA. In contrast, the phosphatase SHP-1 can be activated

Atiprimod, which is an anti-inflammatory compound that is well tolerated in patients with rheumatoid arthritis, is among the natural products that are able to block MM cell proliferation. Atiprimod, a cationic amphiphilic molecule from the azaspirane family of compounds, was shown to induce accumulation of several MM cell lines at the sub$\mathrm{G}_{0} / \mathrm{G}_{1}$ phase of the cell cycle (Amit-Vazina et al. 2005). Atiprimod inhibited the JAK/STAT pathway, leading to the inhibition of STAT3 phosphorylation. As the constitutive activation of STAT3 in myeloma cells results in the upregulation of anti-apoptotic proteins, the effect of Atiprimod on Bcl-2, Bcl-XL and Mcl-1 expression has been assessed in MM cell lines (Catlett-Falcone et al. 1999), and as expected, this compound was found to downregulate the expression of these proteins. Moreover, Atiprimod inhibited IL-6 production, which is involved in MM proliferation through STAT3 activation, resulting in the induction of apoptosis in U266-B1 myeloma cells, which express constitutively active NF- $\kappa \mathrm{B}$ and STAT3. However, NF- $\kappa \mathrm{B}$ expression was also inhibited in Atiprimod-treated MM cells, independently of STAT3, suggesting a role for NF$\kappa \mathrm{B}$ in the mechanism of action of Atiprimod. 
Interestingly, those authors confirmed the effects of Atiprimod on myeloma colony culture assays. Fresh BM samples obtained from five patients with newly diagnosed MM were tested, and Atiprimod suppressed the growth of myeloma colony-forming cells in a dose-dependent manner (Amit-Vazina et al. 2005).

The chalcone butein induced the expression of the tyrosine phosphatase SHP-1, and deletion of the SHP-1 gene by small interfering RNA abolished the ability of butein to inhibit STAT3 activation, suggesting a critical role for SHP-1 in the action of this chalcone (Pandey et al. 2009).

\section{Cutaneous T-cell lymphoma (CTCL)}

Furthermore, a study focusing on the antitumor effect of curcumin on cutaneous T-cell lymphoma (CTCL) cell lines and peripheral blood mononuclear cells (PBMCs) from patients has been reported (Zhang et al. 2010). Curcumin caused more apoptosis in PBMCs from CTCL patients than from healthy donors. At the same concentrations $(5-20 \mu \mathrm{M})$, curcumin induced apoptosis in a time- and dose-dependent manner in MJ-, Hut78- and HH CTCL-derived cell lines. This study suggested that curcumin induced apoptosis in CTCL cells in association with the downregulation of STAT-3 and $\mathrm{NF}-\kappa \mathrm{B}$ signaling pathways. Indeed, whatever the cell lines or patients' PBMCs, STAT-3 protein and mRNA expression levels decreased after curcumin treatment. Moreover, STAT-3 phosphorylation was inhibited and its target genes, bcl-2 and surviving, were downregulated. In addition, curcumin activated caspase- 3 and induced PARP cleavage.

\section{Hepatocellular carcinoma}

Hepatocellular carcinoma (HCC) is the most common primary liver cancer. Currently, the first-line drugs used for HCC include doxorubicin, fluorouracil, cisplatin and mitomycin, but most of these are non-selective cytotoxic molecules with significant side effects. Therefore, it is very important to identify new effective drugs. Among natural compounds from a variety of plants, diosgenin $(\mathrm{Li}$ et al. 2010), B-escin (Tan et al. 2010), butein (Rajendran et al. $2011 \mathrm{~b}$ ) and $\gamma$-tocotrienol (Rajendran et al. 2011a) were reported to inhibit proliferation and to induce apoptosis of HCC cells concomitantly in order to downregulate various STAT3-regulated gene products, including cyclin D1, Bcl2, Bcl-xL, survivin, Mcl-1 and VEGF. These four natural molecules inhibited constitutive and inducible activation of STAT3 through the inhibition of c-Src, JAK1 and JAK2 activation. The pentacyclic triterpenoid $\beta$-escin was recently found to exhibit significant antitumor effects in human hepatocellular carcinoma both in vitro and in vivo (Zhou et al. 2009). In addition, this effect of $\beta$-escin has also been reported to suppress colonic aberrant crypt foci formation in rats and to inhibit growth of colon cancer cells (Patlolla et al. 2006). On the other hand, diosgenin and butein were shown to inhibit P-STAT3 through the induction of phosphatases. Diosgenin, a steroidal saponin isolated from fenugreek, induced the expression of $\mathrm{Src}$ homology 2 phosphatase 2 (SH-PTP2) in correlation with the downregulation of constitutive STAT3 activation in HCC cells ( $\mathrm{Li}$ et al. 2010). As previously described in MM cells, the butein-induced inhibition of P-STAT3 involved SHP-1 activation (Pandey et al. 2009), whereas a phosphatase role for this natural chalcone has not been reported in HCC cells. Interestingly, both diosgenin and butein potentiated the apoptotic effects of paclitaxel and doxorubicin in HCC cells. Moreover, butein inhibited the growth of human HCC xenograft tumors in male athymic nu/nu mice when administered intraperitoneally (Rajendran et al. 2011b). These authors suggested that these compounds are interesting as novel blockers of the STAT3 activation pathway with a potential role in the treatment of HCC.

\section{Cholangiocarcinoma}

Results recently reported by Prakobwong et al. (2011) suggested that curcumin exhibits an anti-cholangiocarcinoma (CCA) potential by suppressing various events involved in multiple steps of carcinogenesis, including its ability to suppress pro-inflammatory pathways. CCA is a major health problem in southeastern Asia because it causes the formation of highly metastatic tumors linked to liver fluke infection and consumption of nitrosamine-contaminated foods.

By using animal models infected with the liver fluke Opisthorchis viverrini and submitted to $N$-nitrosodimethylamine administration, the authors investigated the effect of a curcumin-supplemented diet on CCA development. Under these conditions, there was a significant reduction in the incidence of CCA and an increase in the survival of animals. These observations were in correlation with the suppression of STAT-3 activation as well as of the transcription factors $\mathrm{NF}-\kappa \mathrm{B}$ and AP-1. Moreover, a reduction in the expression of the pro-inflammatory proteins COX-2 and iNOS was also observed. As expected, curcumin induced caspase activation and poly (ADP-Ribose) polymerase (PARP) cleavage while it suppressed the expression of STAT3 target genes, including proteins related to cell survival (Bcl-2 and Bcl$\mathrm{xL}$ ), proliferation (cyclin D1 and c-myc) and angiogenesis (vascular endothelial growth factor, VEGF).

\section{Prostate cancer}

Recent studies have revealed a key role for chronic inflammation in the different stages of prostate cancer 
progression (Damber and Aus 2008). Indeed, prostate cancer proliferation, survival, invasion, metastasis and angiogenesis have been reported to be linked to the NF- $\kappa \mathrm{B}$, STAT3, AKT and COX-2 signaling pathways (Grivennikov and Karin 2010; Yu et al. 2009). However, NF- $\kappa$ B and STAT3 have been particularly implicated in prostate tumor cell survival, metastasis and angiogenesis ( $\mathrm{Li}$ and Sethi 2010). A natural compound, the pentacyclic triterpenoid ursolic acid (UA) (3 $\beta$-hydroxy-urs-12-en-28-oic-acid) (Liu $1995)$, has been reported to be a potent inhibitor of constitutive and inducible STAT3 as well as NF- $\kappa$ B activation in prostate cancer cells (Shanmugam et al. 2011b). The authors also showed that $U A$ significantly suppressed the growth of prostate cancer xenografts in vivo while it was previously reported to be able to inhibit tumor promotion, metastasis, angiogenesis and proliferation of a variety of tumor cells, including human multiple myeloma cells (Pathak et al. 2007) melanoma cells (Manu and Kuttan 2008) and breast cancer cells (Kassi et al. 2009).

Predictive analysis using a virtual tumor cell platform that allows for the determining of the primary target of $U A$ in the prostate cancer cells showed that $U A$ mediates an increase in the apoptotic phenotype by inhibiting STAT3 as well as NF- $\kappa \mathrm{B}$ activity. Moreover, by using human androgen-independent DU145 and androgen-dependent LNCaP prostate cancer cell lines, Shanmugam et al. confirmed that $U A$ inhibited cell proliferation and induced apoptosis in these prostate cancer cells. These effects were correlated with the inhibition of the canonical NF- $\kappa$ B signaling pathway as well as STAT3 phosphorylation through the upstream inhibition of JAK2 and Src activation. As expected, the effect of $U A$ resulted in the downregulation of genes involved in survival and angiogenesis (Shanmugam et al. 2011b). Interestingly, the bioavailability of $U A$ or its metabolites in mice serum was evaluated in this study. Results revealed that $U A$ did not generate any metabolites in the serum and that the concentration of $U A$ was higher than the concentration required to reach in vitro effects. Finally, the circulating concentration was appropriate to trigger inhibition of prostate tumor growth in nude mice. The effects of $U A$ were extended to antimetastatic effects through the suppression of CXCR4 expression in prostate cancer both in vitro and in vivo (Shanmugam et al. 2011a).

\section{Pancreatic cancer}

Regarding pancreatic cancer, the work of Sun et al. (2010) showed that cucurbitacin $E$ of the family of triterpenoids isolated from plants can reduce the phosphorylation of STAT3, leading to inhibition of cell growth, increased expression of p53 and induction of apoptosis of cancer cells. Indeed, p53 can arrest cell cycle progression at different points and induce apoptosis of cells whose growth has become uncontrolled. It is already known that cucurbitacin $E$ has antiproliferative activity in the case of breast, lung and prostate cancer. Earlier work by Sun et al. (2005) had highlighted the fact that this compound acts at the level of lung cancer cells through inhibition of cancer cell growth and induction of apoptosis through downregulation of phosphorylated STAT3.

\section{Leukemia}

In the case of chronic myeloid leukemia, cucurbitacin $B$ from herbaceous plants, belonging to the Cucurbitaceae family, is able to suppress the activation of STAT3. On the basis of the work by Chan et al. (2010), this natural compound can suppress activation of STAT3, resulting in inhibition of cell growth. This phenomenon can be explained by cell cycle arrest or induction of apoptosis. Also in the case of chronic myeloid leukemia, the work of Blasius et al. (2006) showed that curcumin, which is the main pigment derived from the roots of Curcuma longa, also known as turmeric, may inhibit the transcription factor STAT3. This work led to the fact that curcumin is capable of reducing the expression of STAT3 target genes, such as JAK2, v-src, a viral oncogene or cyclin D1, which is involved in regulating the cell cycle. This natural compound plays an important role in the induction of the apoptosis of cancer cells through inhibition of the expression of glutathione $S$-transferase P1-1 (Duvoix et al. 2003), implicated in the detoxification of the cell. Curcumin is in fact implicated in the inhibition of many stages of cancer development, including cell proliferation, angiogenesis and metastasis, by modulating expression and activity of different cell signaling mediators (Kunnumakkara et al. 2008). Besides its effect on STAT3 activity in HCC cells, Sorafenib also showed efficiency in chronic lymphocytic leukemia (CLL) cells, which is the most frequent leukemia. CLL is characterized by an accumulation of monoclonal mature B cells in blood, secondary lymphoid tissues and the marrow. Treatments of mononuclear cells from marrow aspirates of CLL patients led to inhibition of B-RAF, C-RAF, ERK and STAT3 phosphorylation in correlation with Mcl-1 downregulation and resulting in caspasedependent apoptosis (Fecteau et al. 2011). Furthermore, flavopiridol, formerly L86-8275 or HMR 1275, is an hemisynthetic flavonoïd derivative from rohitukine, an alkaloid isolated from the Indian plant Dysoxylum binectariferum (Sedlacek et al. 1996). Flavopiridol was first described as a cyclin-dependent kinase inhibitor (Carlson et al. 1996). Besides its ability to suppress the growth of different tumor types (Arguello et al. 1998; Bible and Kaufmann 1996; Byrd et al. 1998; Carlson et al. 1996; Gojo et al. 2002; Konig et al. 1997; Patel et al. 1998), this compound was shown to induce cell cycle arrest and apoptosis in acute 
myeloid leukemia (AML) in correlation with STAT3 repression (Nelson et al. 2011). Flavopiridol is currently in clinical trials for the treatment of different cancers including AML and ALL (Blum et al. 2010).

\section{Conclusion}

The transcription factor STAT3 is one of the major proteins controlling the transcriptional regulation of many genes involved in essential and housekeeping cellular functions. Its activity results from the activation of signaling pathways and depends on many factors independent from tissue specificity. Therefore, permanent activation of STAT3 triggers perturbation in many tissues, especially the deregulation of cell death and cell cycle, obviously leading to cancer genesis. Constitutive phosphorylation of STAT3 is then considered to be a potential target for the treatment of many cancers and has to be further explored. In this regard, a couple of natural compounds have revealed a potential or a clear capacity to inhibit STAT3 phosphorylation in in vitro and in vivo investigations, leading to the downregulation of target genes in correlation with the induction of apoptosis and the inhibition of cell proliferation. These effects are generally correlated with the inhibition of the phosphorylation of tyr705. This phosphorylation is known to regulate STAT3 dimerization, leading to its translocation to the nucleus and interaction with DNA. Conversely, the role of ser727 phosphorylation of STAT3 is poorly understood, but it is assumed to be positively and negatively involved in the transcriptional activity of STAT3. Few inhibitors of STAT3 with inhibitory activity on ser727 phosphorylation have been reported. Indeed, original articles describing natural inhibitors of STAT3 usually report the effect on tyr705 phosphorylation, as well as of related tyrosine kinases such as JAK or Src, whereas the effect on ser727 is only marginally described. We can assume that most of the compounds are inactive on ser 727 or have likely not been tested so far. Nevertheless, among natural inhibitors, curcumin was shown to inhibit phosphorylation of STAT3 at both tyr705 and ser727 residues in biliary cancer cells (Prakobwong et al. 2011). Interestingly, the inhibition of ser727 phosphorylation has been shown to induce apoptosis in Human B-leukemia and other cell lines constitutively expressing phosphorylated STAT3 in ser727 by curcubitacin-I (JSI-124) (Ishdorj et al. 2010). Obviously, B-leukemia cells are known to express activated STAT3 with constitutive phosphorylation in ser727 but not in tyr705, supporting the role of ser727 phosphorylation in the oncogenic activity of STAT3 and suggesting this residue as a potential target for natural inhibitors of STAT3 activity.

As observed, the molecular structures of the active compounds as inhibitors of STAT3 phosphorylation differ.
Therefore, it may be considered difficult to establish a real relationship between the molecular structures and the inhibitory activity of these natural compounds. However, these compounds act through very similar mechanisms. On the one hand, most of them appear as non-specific inhibitors of STAT3 activity because they do not target functional regions of the protein. On the other hand, they are all described as acting via the inhibition of upstream kinases, such as JAK2 or Src, or as inducers of Src homology 2 phosphatases. One can consider that constitutive activation of STAT3 especially occurs in cancer cells, which would allow for targeting of cancer cells with specific inhibitors of P-STAT3. Nevertheless, the issue concerning the efficiency of very specific inhibitors has to be considered because the action of such molecules would likely be prevented by the continuous stimulation of signaling pathway-mediated STAT3 activation. Indeed, constitutive phosphorylation of STAT3 results from these upstream kinase activities due to mutations or hypersensitivity of cancer cells to stimulatory cytokines. However, inhibiting P-STAT3 at the source of signaling pathways would be challenging because healthy cells would also be affected, unless there is a way to accurately target only tumor cells. Moreover, it must be mentioned that most of the natural compounds described here have been shown to inhibit STAT3 phosphorylation and related signaling pathways in in vitro assays. The effects may be obviously not reproducible in vivo due to the artifacts that occur in cell culture including product half-life or product modifications.

In conclusion, it is unknown what the future holds in terms of alternative therapeutics to inhibit cell proliferation through the inhibition of STAT3 activation. However, the fact that there is an abundance of natural compounds with inhibitory properties against this transcription factor should constitute the molecular basis for the synthesis of more efficient molecules. Some of these compounds have already shown in vivo efficiency against tumors, revealing the necessity of investigating and screening such natural molecules that possess an undeniable promising future in anticancer therapeutics and chemoprevention.

Acknowledgments AT was supported by a grant from the Action Lions "Vaincre le Cancer." Dr. Diederich's research at the Laboratoire de Biologie Moléculaire et Cellulaire du Cancer (LBMCC) is financially supported by the "Recherche Cancer et Sang" foundation, "Recherches Scientifiques Luxembourg," the "Een Häerz fir Kriibskrank Kanner" association, the Action Lions "Vaincre le Cancer" Luxembourg and Televie Luxembourg. Editing and printing costs were covered by the Fonds National de la Recherche (FNR), Luxembourg.

\section{References}

Alas S, Bonavida B (2001) Rituximab inactivates signal transducer and activation of transcription 3 (STAT3) activity in B-non-Hodgkin's 
lymphoma through inhibition of the interleukin 10 autocrine/ paracrine loop and results in down-regulation of Bcl-2 and sensitization to cytotoxic drugs. Cancer Res 61:5137-5144

Amit-Vazina M, Shishodia S, Harris D, Van Q, Wang M, Weber D, Alexanian R, Talpaz M, Aggarwal BB, Estrov Z (2005) Atiprimod blocks STAT3 phosphorylation and induces apoptosis in multiple myeloma cells. Br J Cancer 93:70-80

Arguello F, Alexander M, Sterry JA, Tudor G, Smith EM, Kalavar NT, Greene JF Jr, Koss W, Morgan CD, Stinson SF, Siford TJ, Alvord WG, Klabansky RL, Sausville EA (1998) Flavopiridol induces apoptosis of normal lymphoid cells, causes immunosuppression, and has potent antitumor activity in vivo against human leukemia and lymphoma xenografts. Blood 91:2482-2490

Becker S, Groner B, Muller CW (1998) Three-dimensional structure of the Stat3beta homodimer bound to DNA. Nature 394:145-151

Benekli M, Baer MR, Baumann H, Wetzler M (2003) Signal transducer and activator of transcription proteins in leukemias. Blood 101:2940-2954

Benekli M, Baumann H, Wetzler M (2009) Targeting signal transducer and activator of transcription signaling pathway in leukemias. J Clin Oncol 27:4422-4432

Bharti AC, Donato N, Aggarwal BB (2003) Curcumin (diferuloylmethane) inhibits constitutive and IL-6-inducible STAT3 phosphorylation in human multiple myeloma cells. J Immunol 171: 3863-3871

Bhutani M, Pathak AK, Nair AS, Kunnumakkara AB, Guha S, Sethi G, Aggarwal BB (2007) Capsaicin is a novel blocker of constitutive and interleukin-6-inducible STAT3 activation. Clin Cancer Res 13:3024-3032

Bible KC, Kaufmann SH (1996) Flavopiridol: a cytotoxic flavone that induces cell death in noncycling A549 human lung carcinoma cells. Cancer Res 56:4856-4861

Blasius R, Reuter S, Henry E, Dicato M, Diederich M (2006) Curcumin regulates signal transducer and activator of transcription (STAT) expression in K562 cells. Biochem Pharmacol 72: $1547-1554$

Blaskovich MA, Sun J, Cantor A, Turkson J, Jove R, Sebti SM (2003) Discovery of JSI-124 (cucurbitacin I), a selective Janus kinase/ signal transducer and activator of transcription 3 signaling pathway inhibitor with potent antitumor activity against human and murine cancer cells in mice. Cancer Res 63:1270-1279

Blum W, Phelps MA, Klisovic RB, Rozewski DM, Ni W, Albanese KA, Rovin B, Kefauver C, Devine SM, Lucas DM, Johnson A, Schaaf LJ, Byrd JC, Marcucci G, Grever MR (2010) Phase I clinical and pharmacokinetic study of a novel schedule of flavopiridol in relapsed or refractory acute leukemias. Haematologica 95:1098-1105

Braunstein J, Brutsaert S, Olson R, Schindler C (2003) STATs dimerize in the absence of phosphorylation. J Biol Chem 278: 34133-34140

Byrd JC, Shinn C, Waselenko JK, Fuchs EJ, Lehman TA, Nguyen PL, Flinn IW, Diehl LF, Sausville E, Grever MR (1998) Flavopiridol induces apoptosis in chronic lymphocytic leukemia cells via activation of caspase- 3 without evidence of bcl-2 modulation or dependence on functional p53. Blood 92:3804-3816

Carlson BA, Dubay MM, Sausville EA, Brizuela L, Worland PJ (1996) Flavopiridol induces G1 arrest with inhibition of cyclindependent kinase (CDK) 2 and CDK4 in human breast carcinoma cells. Cancer Res 56:2973-2978

Catlett-Falcone R, Landowski TH, Oshiro MM, Turkson J, Levitzki A, Savino R, Ciliberto G, Moscinski L, Fernandez-Luna JL, Nunez G, Dalton WS, Jove R (1999) Constitutive activation of Stat3 signaling confers resistance to apoptosis in human U266 myeloma cells. Immunity 10:105-115
Chan KT, Li K, Liu SL, Chu KH, Toh M, Xie WD (2010) Cucurbitacin B inhibits STAT3 and the Raf/MEK/ERK pathway in leukemia cell line K562. Cancer Lett 289:46-52

Damber JE, Aus G (2008) Prostate cancer. Lancet 371:1710-1721

Darnell JE Jr (1997) STATs and gene regulation. Science 277: $1630-1635$

Dimopoulos MA, Anagnostopoulos A, Weber D (2003) Treatment of plasma cell dyscrasias with thalidomide and its derivatives. J Clin Oncol 21:4444-4454

Duvoix A, Morceau F, Delhalle S, Schmitz M, Schnekenburger M, Galteau MM, Dicato M, Diederich M (2003) Induction of apoptosis by curcumin: mediation by glutathione S-transferase P1-1 inhibition. Biochem Pharmacol 66:1475-1483

Epling-Burnette PK, Liu JH, Catlett-Falcone R, Turkson J, Oshiro M, Kothapalli R, Li Y, Wang JM, Yang-Yen HF, Karras J, Jove R, Loughran TP Jr (2001) Inhibition of STAT3 signaling leads to apoptosis of leukemic large granular lymphocytes and decreased Mcl-1 expression. J Clin Invest 107:351-362

Fecteau JF, Bharati IS, O'Hayre M, Handel TM, Kipps TJ, Messmer D (2011) Sorafenib-induced apoptosis of chronic lymphocytic leukemia cells is associated with downregulation of RAF and Mcl-1. Mol Med

Glaser T, Winter S, Groscurth P, Safayhi H, Sailer ER, Ammon HP, Schabet M, Weller M (1999) Boswellic acids and malignant glioma: induction of apoptosis but no modulation of drug sensitivity. Br J Cancer 80:756-765

Gojo I, Zhang B, Fenton RG (2002) The cyclin-dependent kinase inhibitor flavopiridol induces apoptosis in multiple myeloma cells through transcriptional repression and down-regulation of Mcl-1. Clin Cancer Res 8:3527-3538

Grad JM, Zeng XR, Boise LH (2000) Regulation of Bcl-xL: a little bit of this and a little bit of STAT. Curr Opin Oncol 12:543-549

Grandage VL, Gale RE, Linch DC, Khwaja A (2005) PI3-kinase/Akt is constitutively active in primary acute myeloid leukaemia cells and regulates survival and chemoresistance via NF-kappaB, Mapkinase and p53 pathways. Leukemia 19:586-594

Grivennikov SI, Karin M (2010) Dangerous liaisons: STAT3 and NF-kappaB collaboration and crosstalk in cancer. Cytokine Growth Factor Rev 21:11-19

Hao W, Hu Y, Niu C, Huang X, Chang CP, Gibbons J, Xu J (2008) Discovery of the catechol structural moiety as a Stat3 SH2 domain inhibitor by virtual screening. Bioorg Med Chem Lett 18:4988-4992

Heinrich PC, Behrmann I, Muller-Newen G, Schaper F, Graeve L (1998) Interleukin-6-type cytokine signalling through the gp130/ Jak/STAT pathway. Biochem J 334(Pt 2):297-314

Hoernlein RF, Orlikowsky T, Zehrer C, Niethammer D, Sailer ER, Simmet T, Dannecker GE, Ammon HP (1999) Acetyl-11-ketobeta-boswellic acid induces apoptosis in HL-60 and CCRF-CEM cells and inhibits topoisomerase I. J Pharmacol Exp Ther 288: 613-619

Horita M, Andreu EJ, Benito A, Arbona C, Sanz C, Benet I, Prosper F, Fernandez-Luna JL (2000) Blockade of the Bcr-Abl kinase activity induces apoptosis of chronic myelogenous leukemia cells by suppressing signal transducer and activator of transcription 5-dependent expression of Bcl-xL. J Exp Med 191:977-984

Ilaria RL Jr, Van Etten RA (1996) P210 and P190(BCR/ABL) induce the tyrosine phosphorylation and DNA binding activity of multiple specific STAT family members. J Biol Chem 271: 31704-31710

Ishdorj G, Johnston JB, Gibson SB (2010) Inhibition of constitutive activation of STAT3 by curcurbitacin-I (JSI-124) sensitized human B-leukemia cells to apoptosis. Mol Cancer Ther 9: $3302-3314$ 
Jing N, Tweardy DJ (2005) Targeting Stat3 in cancer therapy. Anticancer Drugs 16:601-607

Jing N, Zhu Q, Yuan P, Li Y, Mao L, Tweardy DJ (2006) Targeting signal transducer and activator of transcription 3 with G-quartet oligonucleotides: a potential novel therapy for head and neck cancer. Mol Cancer Ther 5:279-286

Kannaiyan R, Shanmugam MK, Sethi G (2011a) Molecular targets of celastrol derived from Thunder of God Vine: potential role in the treatment of inflammatory disorders and cancer. Cancer Lett 303:9-20

Kannaiyan R, Hay HS, Rajendran P, Li F, Shanmugam MK, Vali S, Abbasi T, Kapoor S, Sharma A, Kumar AP, Chng WJ, Sethi G (2011b) Celastrol inhibits proliferation and induces chemosensitization through down-regulation of NF-kappaB and STAT3 regulated gene products in multiple myeloma cells. $\mathrm{Br} \mathrm{J}$ Pharmacol 164(5):1506-1521

Kassi E, Sourlingas TG, Spiliotaki M, Papoutsi Z, Pratsinis H, Aligiannis N, Moutsatsou P (2009) Ursolic acid triggers apoptosis and Bcl-2 downregulation in MCF-7 breast cancer cells. Cancer Invest 27:723-733

Konig A, Schwartz GK, Mohammad RM, Al-Katib A, Gabrilove JL (1997) The novel cyclin-dependent kinase inhibitor flavopiridol downregulates Bcl-2 and induces growth arrest and apoptosis in chronic B-cell leukemia lines. Blood 90:4307-4312

Kunnumakkara AB, Anand P, Aggarwal BB (2008) Curcumin inhibits proliferation, invasion, angiogenesis and metastasis of different cancers through interaction with multiple cell signaling proteins. Cancer Lett 269:199-225

Lee SO, Lou W, Qureshi KM, Mehraein-Ghomi F, Trump DL, Gao AC (2004) RNA interference targeting Stat 3 inhibits growth and induces apoptosis of human prostate cancer cells. Prostate 60: 303-309

Leong PL, Andrews GA, Johnson DE, Dyer KF, Xi S, Mai JC, Robbins PD, Gadiparthi S, Burke NA, Watkins SF, Grandis JR (2003) Targeted inhibition of Stat3 with a decoy oligonucleotide abrogates head and neck cancer cell growth. Proc Natl Acad Sci USA 100:4138-4143

Li F, Sethi G (2010) Targeting transcription factor NF-kappaB to overcome chemoresistance and radioresistance in cancer therapy. Biochim Biophys Acta 1805:167-180

Li F, Rajendran P, Sethi G (2010a) Thymoquinone inhibits proliferation, induces apoptosis and chemosensitizes human multiple myeloma cells through suppression of signal transducer and activator of transcription 3 activation pathway. Br J Pharmacol 161:541-554

Li F, Fernandez PP, Rajendran P, Hui KM, Sethi G (2010b) Diosgenin, a steroidal saponin, inhibits STAT3 signaling pathway leading to suppression of proliferation and chemosensitization of human hepatocellular carcinoma cells. Cancer Lett 292: 197-207

Liu J (1995) Pharmacology of oleanolic acid and ursolic acid. J Ethnopharmacol 49:57-68

Liu JJ, Nilsson A, Oredsson S, Badmaev V, Zhao WZ, Duan RD (2002a) Boswellic acids trigger apoptosis via a pathway dependent on caspase- 8 activation but independent on Fas/Fas ligand interaction in colon cancer HT-29 cells. Carcinogenesis 23:2087-2093

Liu P, Kimmoun E, Legrand A, Sauvanet A, Degott C, Lardeux B, Bernuau D (2002b) Activation of NF-kappa B, AP-1 and STAT transcription factors is a frequent and early event in human hepatocellular carcinomas. J Hepatol 37:63-71

Manu KA, Kuttan G (2008) Ursolic acid induces apoptosis by activating p53 and caspase- 3 gene expressions and suppressing NF-kappaB mediated activation of bcl-2 in $\mathrm{B} 16 \mathrm{~F}-10$ melanoma cells. Int Immunopharmacol 8:974-981
Martin P, Papayannopoulou T (1982) HEL cells: a new human erythroleukemia cell line with spontaneous and induced globin expression. Science 216:1233-1235

Mertens C, Zhong M, Krishnaraj R, Zou W, Chen X, Darnell JE Jr (2006) Dephosphorylation of phosphotyrosine on STAT1 dimers requires extensive spatial reorientation of the monomers facilitated by the N-terminal domain. Genes Dev 20:3372-3381

Meydan N, Grunberger T, Dadi H, Shahar M, Arpaia E, Lapidot Z, Leeder JS, Freedman M, Cohen A, Gazit A, Levitzki A, Roifman CM (1996) Inhibition of acute lymphoblastic leukaemia by a Jak-2 inhibitor. Nature 379:645-648

Nagel-Wolfrum K, Buerger C, Wittig I, Butz K, Hoppe-Seyler F, Groner B (2004) The interaction of specific peptide aptamers with the DNA binding domain and the dimerization domain of the transcription factor Stat3 inhibits transactivation and induces apoptosis in tumor cells. Mol Cancer Res 2:170-182

Nelson DM, Joseph B, Hillion J, Segal J, Karp JE, Resar LM (2011) Flavopiridol induces BCL-2 expression and represses oncogenic transcription factors in leukemic blasts from adults with refractory acute myeloid leukemia. Leuk Lymphoma 52: 1999-2006

Niu G, Wright KL, Ma Y, Wright GM, Huang M, Irby R, Briggs J, Karras J, Cress WD, Pardoll D, Jove R, Chen J, Yu H (2005) Role of Stat 3 in regulating p53 expression and function. Mol Cell Biol 25:7432-7440

Niwa Y, Kanda H, Shikauchi Y, Saiura A, Matsubara K, Kitagawa T, Yamamoto J, Kubo T, Yoshikawa H (2005) Methylation silencing of SOCS-3 promotes cell growth and migration by enhancing JAK/STAT and FAK signalings in human hepatocellular carcinoma. Oncogene 24:6406-6417

Ozawa Y, Williams AH, Estes ML, Matsushita N, Boschelli F, Jove R, List AF (2008) Src family kinases promote AML cell survival through activation of signal transducers and activators of transcription (STAT). Leuk Res 32:893-903

Pandey MK, Sung B, Ahn KS, Aggarwal BB (2009) Butein suppresses constitutive and inducible signal transducer and activator of transcription (STAT) 3 activation and STAT3regulated gene products through the induction of a protein tyrosine phosphatase SHP-1. Mol Pharmacol 75:525-533

Park YS, Lee JH, Harwalkar JA, Bondar J, Safayhi H, Golubic M (2002) Acetyl-11-keto-beta-boswellic acid (AKBA) is cytotoxic for meningioma cells and inhibits phosphorylation of the extracellular-signal regulated kinase 1 and 2. Adv Exp Med Biol 507:387-393

Patel V, Senderowicz AM, Pinto D Jr, Igishi T, Raffeld M, Quintanilla-Martinez L, Ensley JF, Sausville EA, Gutkind JS (1998) Flavopiridol, a novel cyclin-dependent kinase inhibitor, suppresses the growth of head and neck squamous cell carcinomas by inducing apoptosis. J Clin Invest 102:1674-1681

Pathak AK, Bhutani M, Nair AS, Ahn KS, Chakraborty A, Kadara H, Guha S, Sethi G, Aggarwal BB (2007) Ursolic acid inhibits STAT3 activation pathway leading to suppression of proliferation and chemosensitization of human multiple myeloma cells. Mol Cancer Res 5:943-955

Patlolla JM, Raju J, Swamy MV, Rao CV (2006) Beta-escin inhibits colonic aberrant crypt foci formation in rats and regulates the cell cycle growth by inducing p21(waf1/cip1) in colon cancer cells. Mol Cancer Ther 5:1459-1466

Paulson M, Press C, Smith E, Tanese N, Levy DE (2002) IFNStimulated transcription through a TBP-free acetyltransferase complex escapes viral shutoff. Nat Cell Biol 4:140-147

Pellegrini S, Dusanter-Fourt I (1997) The structure, regulation and function of the Janus kinases (JAKs) and the signal transducers and activators of transcription (STATs). Eur J Biochem 248: 615-633 
Pettersson M, Jernberg-Wiklund H, Larsson LG, Sundstrom C, Givol I, Tsujimoto Y, Nilsson K (1992) Expression of the bcl-2 gene in human multiple myeloma cell lines and normal plasma cells. Blood 79:495-502

Prakobwong S, Khoontawad J, Yongvanit P, Pairojkul C, Hiraku Y, Sithithaworn P, Pinlaor P, Aggarwal BB, Pinlaor S (2011a) Curcumin decreases cholangiocarcinogenesis in hamsters by suppressing inflammation-mediated molecular events related to multistep carcinogenesis. Int J Cancer 129:88-100

Prakobwong S, Gupta SC, Kim JH, Sung B, Pinlaor P, Hiraku Y, Wongkham S, Sripa B, Pinlaor S, Aggarwal BB (2011b) Curcumin suppresses proliferation and induces apoptosis in human biliary cancer cells through modulation of multiple cell signaling pathways. Carcinogenesis 32:1372-1380

Rajendran P, Li F, Manu KA, Shanmugam MK, Loo SY, Kumar AP, Sethi G (2011a) gamma-Tocotrienol is a novel inhibitor of constitutive and inducible STAT3 signalling pathway in human hepatocellular carcinoma: potential role as an antiproliferative, pro-apoptotic and chemosensitizing agent. Br J Pharmacol 163: 283-298

Rajendran P, Ong TH, Chen L, Li F, Shanmugam MK, Vali S, Abbasi T, Kapoor S, Sharma A, Kumar AP, Hui KM, Sethi G (2011b) Suppression of signal transducer and activator of transcription 3 activation by butein inhibits growth of human hepatocellular carcinoma in vivo. Clin Cancer Res 17:1425-1439

Rascle A, Johnston JA, Amati B (2003) Deacetylase activity is required for recruitment of the basal transcription machinery and transactivation by STAT5. Mol Cell Biol 23:4162-4173

Ren Z, Cabell LA, Schaefer TS, McMurray JS (2003) Identification of a high-affinity phosphopeptide inhibitor of Stat3. Bioorg Med Chem Lett 13:633-636

Schindler C, Plumlee C (2008) Interferons pen the JAK-STAT pathway. Semin Cell Dev Biol 19:311-318

Schindler C, Levy DE, Decker T (2007) JAK-STAT signaling: from interferons to cytokines. J Biol Chem 282:20059-20063

Schust J, Sperl B, Hollis A, Mayer TU, Berg T (2006) Stattic: a smallmolecule inhibitor of STAT3 activation and dimerization. Chem Biol 13:1235-1242

Sedlacek H, Czech J, Naik R, Kaur G, Worland P, Losiewicz M, Parker B, Carlson B, Smith A, Senderowicz A, Sausville E (1996) Flavopiridol (L86 8275; NSC 649890), a new kinase inhibitor for tumor therapy. Int J Oncol 9:1143-1168

Shanmugam MK, Manu KA, Ong TH, Ramachandran L, Surana R, Bist P, Lim LH, Kumar AP, Hui KM, Sethi G (2011a) Inhibition of CXCR4/CXCL12 signaling axis by ursolic acid leads to suppression of metastasis in transgenic adenocarcinoma of mouse prostate model. Int J Cancer 129(7):1552-1563

Shanmugam MK, Rajendran P, Li F, Nema T, Vali S, Abbasi T, Kapoor S, Sharma A, Kumar AP, Ho PC, Hui KM, Sethi G (2011b) Ursolic acid inhibits multiple cell survival pathways leading to suppression of growth of prostate cancer xenograft in nude mice. J Mol Med 89:713-727

Shao Y, Ho CT, Chin CK, Badmaev V, Ma W, Huang MT (1998) Inhibitory activity of boswellic acids from Boswellia serrata against human leukemia HL-60 cells in culture. Planta Med 64: 328-331

Shin DS, Kim HN, Shin KD, Yoon YJ, Kim SJ, Han DC, Kwon BM (2009) Cryptotanshinone inhibits constitutive signal transducer and activator of transcription 3 function through blocking the dimerization in DU145 prostate cancer cells. Cancer Res 69: 193-202

Siddiquee K, Zhang S, Guida WC, Blaskovich MA, Greedy B, Lawrence HR, Yip ML, Jove R, McLaughlin MM, Lawrence NJ, Sebti SM, Turkson J (2007a) Selective chemical probe inhibitor of Stat3, identified through structure-based virtual screening, induces antitumor activity. Proc Natl Acad Sci USA 104: 7391-7396

Siddiquee KA, Gunning PT, Glenn M, Katt WP, Zhang S, Schrock C, Sebti SM, Jove R, Hamilton AD, Turkson J (2007b) An oxazolebased small-molecule Stat3 inhibitor modulates Stat 3 stability and processing and induces antitumor cell effects. ACS Chem Biol 2:787-798

Song H, Wang R, Wang S, Lin J (2005) A low-molecular-weight compound discovered through virtual database screening inhibits Stat3 function in breast cancer cells. Proc Natl Acad Sci USA 102:4700-4705

Spiekermann K, Biethahn S, Wilde S, Hiddemann W, Alves F (2001) Constitutive activation of STAT transcription factors in acute myelogenous leukemia. Eur J Haematol 67:63-71

Staerk J, Kallin A, Royer Y, Diaconu CC, Dusa A, Demoulin JB, Vainchenker W, Constantinescu SN (2007) JAK2, the JAK2 V617F mutant and cytokine receptors. Pathol Biol (Paris) 55: 88-91

Sun J, Blaskovich MA, Jove R, Livingston SK, Coppola D, Sebti SM (2005) Cucurbitacin Q: a selective STAT3 activation inhibitor with potent antitumor activity. Oncogene 24:3236-3245

Sun C, Zhang M, Shan X, Zhou X, Yang J, Wang Y, Li-Ling J, Deng $Y$ (2010) Inhibitory effect of cucurbitacin $E$ on pancreatic cancer cells growth via STAT3 signaling. J Cancer Res Clin Oncol 136: 603-610

Syrovets T, Gschwend JE, Buchele B, Laumonnier Y, Zugmaier W, Genze F, Simmet T (2005) Inhibition of IkappaB kinase activity by acetyl-boswellic acids promotes apoptosis in androgenindependent $\mathrm{PC}-3$ prostate cancer cells in vitro and in vivo. J Biol Chem 280:6170-6180

Tan SM, Li F, Rajendran P, Kumar AP, Hui KM, Sethi G (2010) Identification of beta-escin as a novel inhibitor of signal transducer and activator of transcription 3/Janus-activated kinase 2 signaling pathway that suppresses proliferation and induces apoptosis in human hepatocellular carcinoma cells. J Pharmacol Exp Ther 334:285-293

Timofeeva OA, Gaponenko V, Lockett SJ, Tarasov SG, Jiang S, Michejda CJ, Perantoni AO, Tarasova NI (2007) Rationally designed inhibitors identify STAT3 $\mathrm{N}$-domain as a promising anticancer drug target. ACS Chem Biol 2:799-809

Tu Y, Renner S, Xu F, Fleishman A, Taylor J, Weisz J, Vescio R, Rettig M, Berenson J, Krajewski S, Reed JC, Lichtenstein A (1998) BCL-X expression in multiple myeloma: possible indicator of chemoresistance. Cancer Res 58:256-262

Turkson J, Ryan D, Kim JS, Zhang Y, Chen Z, Haura E, Laudano A, Sebti S, Hamilton AD, Jove R (2001) Phosphotyrosyl peptides block Stat3-mediated DNA binding activity, gene regulation, and cell transformation. J Biol Chem 276:45443-45455

Turkson J, Zhang S, Palmer J, Kay H, Stanko J, Mora LB, Sebti S, Yu H, Jove R (2004a) Inhibition of constitutive signal transducer and activator of transcription 3 activation by novel platinum complexes with potent antitumor activity. Mol Cancer Ther 3: $1533-1542$

Turkson J, Kim JS, Zhang S, Yuan J, Huang M, Glenn M, Haura E, Sebti S, Hamilton AD, Jove R (2004b) Novel peptidomimetic inhibitors of signal transducer and activator of transcription 3 dimerization and biological activity. Mol Cancer Ther 3: 261-269

Turkson J, Zhang S, Mora LB, Burns A, Sebti S, Jove R (2005) A novel platinum compound inhibits constitutive Stat 3 signaling and induces cell cycle arrest and apoptosis of malignant cells. J Biol Chem 280:32979-32988

Waris G, Siddiqui A (2005) Hepatitis C virus stimulates the expression of cyclooxygenase-2 via oxidative stress: role of prostaglandin E2 in RNA replication. J Virol 79:9725-9734 
Weidler M, Rether J, Anke T, Erkel G (2000) Inhibition of interleukin- 6 signaling by galiellalactone. FEBS Lett 484:1-6

Yoshida T, Hanada T, Tokuhisa T, Kosai K, Sata M, Kohara M, Yoshimura A (2002) Activation of STAT3 by the hepatitis C virus core protein leads to cellular transformation. J Exp Med 196:641-653

Yu H, Pardoll D, Jove R (2009) STATs in cancer inflammation and immunity: a leading role for STAT3. Nat Rev Cancer 9:798-809

Yue P, Turkson J (2009) Targeting STAT3 in cancer: how successful are we? Expert Opin Investig Drugs 18:45-56

Zhang C, Li B, Zhang X, Hazarika P, Aggarwal BB, Duvic M (2010) Curcumin selectively induces apoptosis in cutaneous T-cell lymphoma cell lines and patients' PBMCs: potential role for STAT-3 and NF-kappaB signaling. J Invest Dermatol 130: 2110-2119

Zhao W, Zhang T, Qu B, Wu X, Zhu X, Meng F, Gu Y, Shu Y, Shen Y, Sun Y, Xu Q (2011) Sorafenib induces apoptosis in HL60 cells by inhibiting Src kinase-mediated STAT3 phosphorylation. Anticancer Drugs 22:79-88

Zhou J, Smith DK, Lu L, Poon VK, Ng F, Chen DQ, Huang JD, Yuen KY, Cao KY, Zheng BJ (2009) A non-synonymous single nucleotide polymorphism in IFNAR1 affects susceptibility to chronic hepatitis B virus infection. J Viral Hepat 16:45-52 